\title{
Mitochondrial D-loop nucleotide diversity in Astyanax (Osteichthyes, Characidae) from the upper Paraná and upper Paraguay River basins
}

\author{
A.J. Prioli ${ }^{1,2}$, V.A. Carlo ${ }^{2,3}$, T.V. Soria ${ }^{2,4}$, S.M.A.P. Prioli ${ }^{1,2}$, C.S. Pavanelli ${ }^{2}$, \\ R.A. Prioli ${ }^{2}$, V.N. Gomes ${ }^{2,3}$, H.F. Júlio Jr. ${ }^{1,2}$ and L.M. Prioli ${ }^{2}$ \\ ${ }^{1}$ Departamento de Biologia Celular e Genética, \\ Universidade Estadual de Maringá, Maringá, PR, Brasil \\ ${ }^{2}$ Núcleo de Pesquisas em Limnologia Ictiologia e Aquicultura, \\ Universidade Estadual de Maringá, Maringá, PR, Brasil \\ ${ }^{3}$ Pós-Graduação em Ecologia de Ambientes Aquáticos Continentais, \\ Universidade Estadual de Maringá, Maringá, PR, Brasil \\ ${ }^{4}$ Pós-Graduação em Genética e Melhoramento, \\ Universidade Estadual de Maringá, Maringá, PR, Brasil
}

Corresponding author: A.J. Prioli

E-mail: ajprioli@nupelia.uem.br

Genet. Mol. Res. 11 (2): 1064-1074 (2012)

Received May 11, 2011

Accepted December 5, 2011

Published April 27, 2012

DOI http://dx.doi.org/10.4238/2012.April.27.5

\begin{abstract}
The morphological discrimination between the species Astyanax altiparanae and A. asuncionensis of the upper Paraná River and Paraguay River basins, respectively, has always been difficult. Two D-loop haplogroups of $A$. altiparanae are known, one with the presence (AltoPR) or the absence (AltoPR-D) of a 32-bp block similar to that in $A$. asuncionensis. We examined these samples to characterize $A$. altiparanae and verify whether $A$. asuncionensis occurred in the upper Paraná River prior to the submergence of the Sete Quedas Falls when Itaipu reservoir was impounded. D-loop sequences were analyzed in A. altiparanae of the upper Paraná and Iguaçu Rivers and those of $A$. asuncionensis of the upper Paraguay River. The haplogroup AltoPR was found at all sites of the
\end{abstract}


upper Paraná and Iguaçu Rivers, whereas AltoPR-D occurred in the Itaipu reservoir, floodplain and in the Tietê and Grande Rivers. Two haplogroups of $A$. asuncionensis were identified and both did not have the 32-bp block. However, AltoPR and AltoPR-D differed from one another in 5.1\% of their bases and between 8.9 and $12.5 \%$ with regard to the haplogroups of the upper Paraguay basin. Further, AltoPR-D occurred in the Grande River upstream the Marimbondo Falls and other older reservoirs than Itaipu. The results reject the hypothesis of the establishment of $A$. asuncionensis and suggest that the haplogroup AltoPR-D existed in the upper Paraná River before the impounding of the Itaipu reservoir. Moreover, morphological similarity and high genetic variation within the altiparanaelasuncionensis group suggest the existence of a cryptic species complex.

Key words: Astyanax altiparanae; Astyanax asuncionensis; Mitochondrial DNA; Species discrimination

\section{INTRODUCTION}

The formation of new barriers to natural migration of many fish species and consequent isolation of populations is a problem that normally occurs when reservoirs are built in rivers. On the other hand, intense river impounding may erase natural geographical barriers changing the migration pattern of several fish species and allowing the introduction of others in formerly inaccessible regions. Environmental impacts in those cases may modify the genetic variability or structure of fish populations (Oliveira et al., 2002). There is also extreme possibility of extinction of species that are less adapted to tackle environmental alterations (Agostinho et al., 1992, 1993; Agostinho and Júlio Jr., 1999).

The Sete Quedas Falls constituted a natural barrier that separated two distinct ichthyofaunistic regions in the Paraná River, namely, upper and lower Paraná River basins. When the Itaipu reservoir was formed and the Sete Quedas Falls submerged, subsequent displacement and incorporation of a $150-\mathrm{km}$ stretch of the lower Paraná River to the upper occurred. The current ichthyofauna of the floodplain of the upper Paraná River is thus peculiar since several species of the lower Paraná River have co-existed with the local ichthyofauna during the last 30 years. Research undertaken during the last decades in that floodplain has identified 170 fish species, including 33 species from the lower Paraná that succeeded after the Itaipu reservoir enclosure (Júlio Jr. et al., 2009). Furthermore, several fish species from other Brazilian basins and even from other countries have been introduced in that reservoir for stocking and/or repopulation strategies (Júlio Jr. et al., 2009).

The 88 Incertae sedis genera in Characidae comprise approximately 620 species, of which 86 belong to the genus Astyanax (Lima et al., 2003). Although Astyanax bimaculatus belongs to the Amazon basin, it also occurs in the Paraná and Paraguay River basins (Garutti, 1995). Garutti and Britski (2000) taxonomically revised species of Astyanax from the upper Paraná River, previously identified as A. bimaculatus, and described it as a different species named A. altiparanae. According to Lima et al. (2003), the species from the lower Paraná and Paraguay River basins, previously also misidentified as A. bimaculatus, is currently identified as A. asuncionensis Géry, 1972 (Figure 1). 


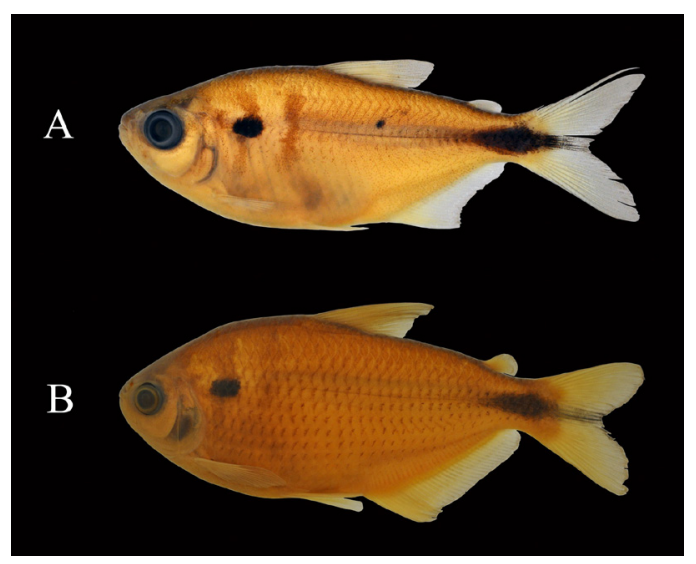

Figure 1. A. Astyanax altiparanae NUP 11584, $56.0 \mathrm{~mm}$ SL. B. A. asunsionensis NUP 935, $85.0 \mathrm{~mm}$ SL.

The evolution rate of the control region, or D-loop, of mitochondrial DNA (mtDNA) is twice to five times higher than that of protein-codifying mitochondrial genes (Faber and Stepien, 1977; Meyer, 1994; Sivasundar et al., 2001; Rokas et al., 2003; Avise, 2004). Although D-loop region may be eventually used in phylogenetic analyses of distant taxa, as undertaken by Ortí et al. (2008) with the family Serrassalmidae, agreement has been reached that this mitochondrial sequence is more effective in intra-species comparative analyses or between very close species (Prioli et al., 2002; Oliveira et al., 2002, 2006; Batista and AlvesGomes, 2006; Panarari-Antunes et al., 2008).

The species $A$. altiparanae has been recently identified in the Iguaçu River (Graça and Pavanelli, 2002; Prioli et al., 2002) through their morphological characteristics and molecular markers. That river is an affluent of the Paraná River just downstream from the Itaipu dam, but its larger extension is completely isolated by the Cataratas, very high falls close to its mouth that act as effective barriers to free dispersal of fish, and provide an elevated degree of endemism of its ichthyofauna. RAPD and mtDNA markers showed that the A. altiparanae population from the Iguaçu River was recently introduced from the upper Paraná River (Prioli et al., 2002). Pie et al. (2009) also employ D-loop sequences to characterize several Astyanax species endemic to the Iguaçu River basin. However, the highly abundant and important foodchain species $A$. altiparanae is still little known from the genetic and population point of view.

Occurrence indications of pronounced variation in mtDNA, unexpected within genetically stable populations, were reported within a population identified as A. altiparanae, which inhabits the upper Paraná River floodplain. Primarily, a 32-bp block absence was detected in the D-loop hypervariable region present in many individuals of Astyanax from the upper Paraná River. Such diversity may have occurred due to the introduction of a new variant of $A$. altiparanae or a proximate species in the floodplain (Soria et al., 2003). Soria (2004) reported that the variant haplogroup is alike to that found in A. asuncionensis from the Manso River, Paraguay River basin.

On the other hand, Soria (2004) failed to analyze the several Astyanax that occur upstream in the lockless reservoirs, which had been built some years before the Itaipu reservoir, such as the Marimbondo reservoir in the Grande River. If $A$. asuncionensis invaded the upper 
Paraná River basin when Itaipu impounded the river, it might be expected that the species would not have colonized regions upstream from the Marimbondo dam.

The current essay investigates the genetic diversity among Astyanax populations from the upper Paraná River basin and the Manso River, in the upper Paraguay River basin, by mtDNA D-loop nucleotide sequences. It intends to be a contribution towards a better characterization of $A$. altiparanae and to verify the possibility that $A$. asuncionensis may have established itself in the upper Paraná River.

\section{MATERIAL AND METHODS}

Specimens identified as A. altiparanae were analyzed from seven sites of the upper Paraná and Iguaçu River basins. A. asuncionensis specimens were collected in the Manso River, State of Mato Grosso do Sul, Brazil, upper Paraguay River basin. Figure 2 shows the sampling sites. Voucher specimens were deposited in the Coleção Ictiológica do Nupélia, as NUP 935 and NUP 11584. D-loop sequences of Astyanax from several sites mentioned above, available in the GenBank ${ }^{\circledR}$, were employed. Further, sequences prepared by Soria (2004) and those available in the GenBank ${ }^{\circledR}$ prepared by Prioli et al. (2002) were also included in the current analysis.

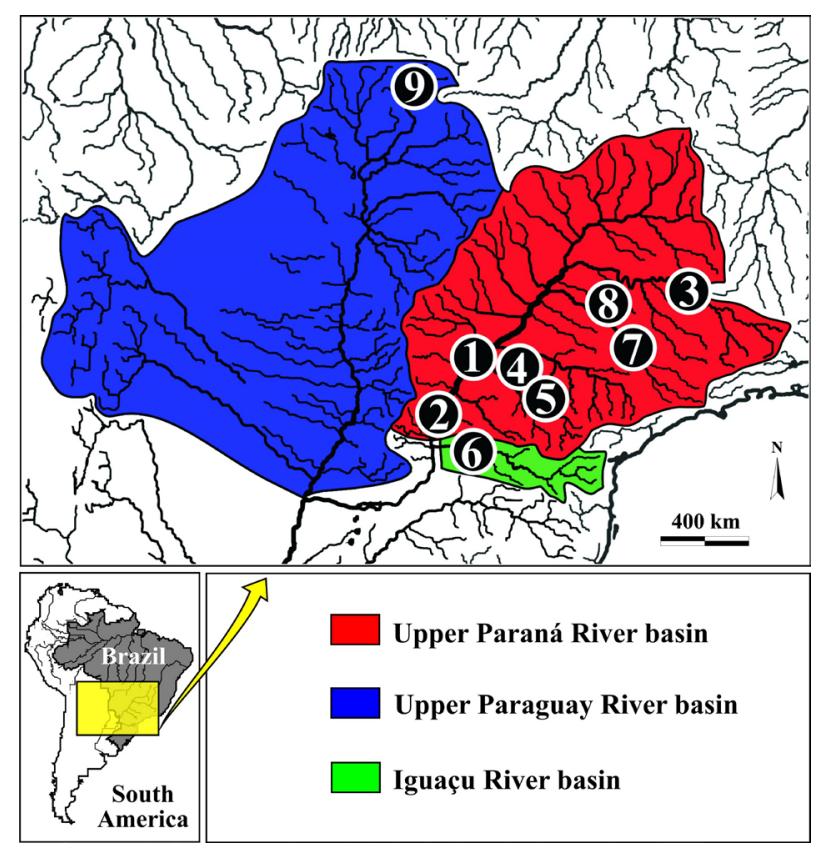

Figure 2. Sampling locations of Astyanax altiparanae and A. asuncionensis. Numbers are sampling sites: $1=$ Upper Paraná River floodplain (Porto Rico, PR - 22 ${ }^{\circ} 45^{\prime} \mathrm{S} / 53^{\circ} 15^{\prime} \mathrm{W}$ ); 2 = Itaipu reservoir in the Paraná River (Entre Rios, PR - $\left.24^{\circ} 43^{\prime} \mathrm{S} / 54^{\circ} 16^{\prime} \mathrm{W}\right) ; 3=$ Estreito reservoir in the Grande River (Pedregulho, SP - $24^{\circ} 43^{\prime} \mathrm{S} / 54^{\circ} 16^{\prime} \mathrm{W}$ ); 4

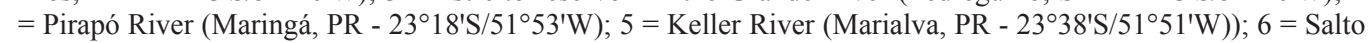
Caxias reservoir in the Iguaçu River (Três Barras do Paraná, PR - $25^{\circ} 27^{\prime} \mathrm{S} / 53^{\circ} 18^{\prime} \mathrm{W}$ ); 7 = Barra Bonita reservoir in the Tietê River (Barra Bonita, SP - $22^{\circ} 31^{\prime} \mathrm{S} / 48^{\circ} 31^{\prime} \mathrm{W}$ ); $8=$ Municipal dam of Monte Aprazível, SP, in the São José dos Dourados River basin $\left(20^{\circ} 46^{\prime} \mathrm{S} / 49^{\circ} 43^{\prime} \mathrm{W}\right) ; 9=$ Manso River in the Paraguay River basin (Rosário Oeste, MT - $\left.14^{\circ} 48^{\prime} \mathrm{S} / 56^{\circ} 05^{\prime} \mathrm{W}\right)$. 
Commercial alcohol was injected into the fish's abdominal cavity after collection for preserving the specimens. Whole specimens were placed in commercial alcohol-filled flasks and stored at $-20^{\circ} \mathrm{C}$. Total DNA was extracted by the phenol-chloroform method according to Monesi et al. (1998), with few modifications.

An mtDNA fragment, containing a partial sequence of the control region, or D-loop, was amplified by PCR from DNA samples, according to Prioli et al. (2002). Amplified fragments, approximately $760 \mathrm{bp}$, contain the hypervariable extremity $5^{\prime}$ of the D-loop region's heavy strand of the mtDNA molecule. Primers were H16498 5'-CCTGAAGTAGGAACCAGATG-3' (Meyer et al., 1990) and L15774M 5'-CAACATGAATTGGAGGTATACCAGT-3' (Prioli et al., 2002). The final product from each PCR was directly used as a sample for sequencing on platform ABI-3100 (Perkin Elmer, Norwalk, CT, USA).

Sequences were edited and aligned by CLUSTAL W using the BioEdit software (Hall, 1999). Deletion sites were not included in the analyses since evolution significance of deletions in DNA sequences is not thoroughly known (Nei and Kumar, 2000). Employing procedures of corrected Akaike Information Criterion and Bayesian Information Criterion of Modeltest 3.7 (Posada and Crandall, 1998), the evolution model HKY85 + I $+\Gamma$ produced the best data adjustment. Phylogenetic relationships between mitochondrial haplotypes were obtained by PHYML (Guindon and Gascuel, 2003), using the maximum likelihood method with HKY85 $+\mathrm{I}+\Gamma$ model. Bootstrap analyses were based on 1000 replications.

\section{RESULTS}

Sequences of the D-loop's hypervariable extremity 5' of Astyanax with approximately $424 \mathrm{bp}$ were obtained. In the current research, 30 sequences were obtained from the upper Paraná River basin and from the Manso River of the upper Paraguay River basin. Other 50 sequences were previously obtained by Prioli et al. (2002) and Soria (2004). Sixty-six D-loop sequences of specimens from the upper Paraná River, 6 from the Iguaçu River and 8 from the Paraguay River basin were analyzed.

All specimens collected from the upper Paraná and from the Iguaçu River basins were identified as $A$. altiparanae. Identification was based on traditional morphological characteristics, following Garutti and Britski (2000). On the other hand, specimens from the Manso River were identified as A. asuncionensis, according to Britski et al. (2007). However, it should be underscored that consistent discrimination solely on traditional morphological bases was not possible. This was due to the extensive overlapping of characteristics of both species. Consequently, specimens were identified mainly considering their origin more than their characteristics.

A total of 158 polymorphic nucleotide sites were found within the 80 analyzed sequences (Table 1). The proportion of bases $(\mathrm{T}=38.3 ; \mathrm{C}=13.2 ; \mathrm{A}=38.7 ; \mathrm{G}=9.8)$ and the ratio of transitions and transversions $(\mathrm{R}=\mathrm{si} / \mathrm{sv}=2.4)$ agree with what was expected for $\mathrm{D}$-loop mitochondrial sequences, namely, a higher proportion of pyrimidines and a higher transition rate (Nei and Kumar, 2000). An indel from a 32-bp block can be identified in Table 1 as the most evident characteristic. The 32-bp block does not seem to be an in tandem repetition unit, as common in D-loop region of the mtDNA. Even if the 32-bp block is discarded, polymorphisms in other nucleotide sites characterize four highly differentiated haplogroups. 
Mitochondrial nucleotide diversity in Astyanax
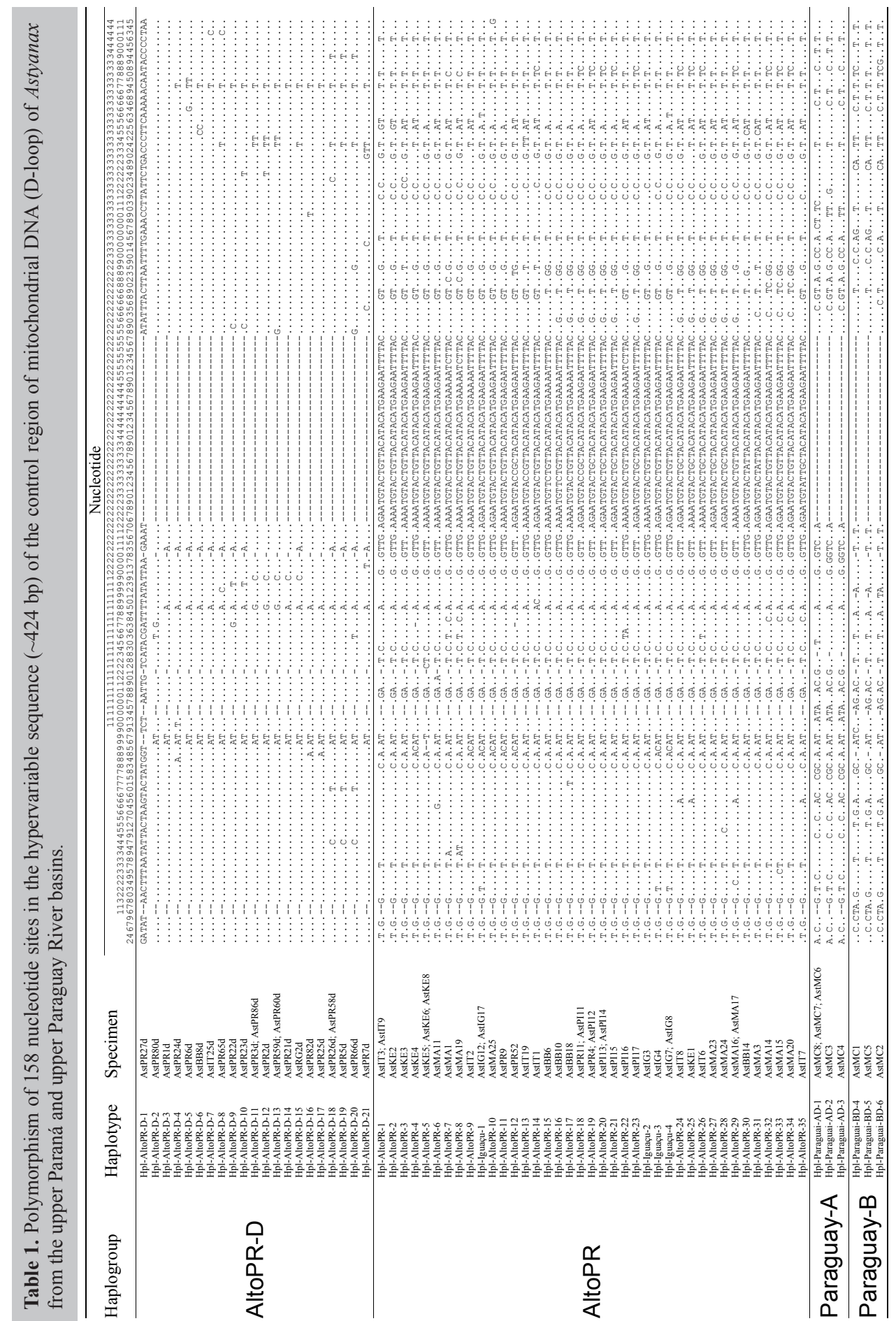

Genetics and Molecular Research 11 (2): 1064-1074 (2012) 
Two haplogroups may be easily recognized among specimens identified as A. altiparanae from the upper Paraná and Iguaçu River basins. Haplogroup AltoPR, with 39 haplotypes, is differentiated by marking presence of 32-bp block. Haplogroup AltoPR is extensively spread throughout the whole basins of the upper Paraná and the Iguaçu Rivers. However, it was not found in the Paraguay River basin.

Contrastingly, a second haplogroup with 23 haplotypes, exclusive to the upper Paraná River basin specimens, is characterized by lacking the 32-bp block that, according to Soria (2004), was found in A. asunsionensis. The haplogroup was called AltoPR-D due to a deletion, even though it is not yet possible to determine whether the absence of the block has originated by deletion or by insertion. Haplotypes within AltPR-D were reported in the Itaipu reservoir, in the floodplain of the upper Paraná River, in the Barra Bonita reservoir, Tietê River, and in the Grande River, upstream from the Marimbondo reservoir.

Specimens identified as A. asuncionensis from the Manso River region formed two highly differentiated haplogroups by their nucleotide sequences. Whereas haplogroup Paraguay-A in the studied sample is represented by five haplotypes, the haplogroup Paraguay-B comprises three haplotypes. The two haplogroups, however, are characterized by lacking the 32-bp block.

Table 2 shows the diversity among haplogroups, taken two by two. The number and percentage of nucleotide sites outside the 32-bp block are shown so that the haplogroups may be diagnosed. Criteria for discrimination of two haplogroups are: one site should be monomorphic in one haplogroup and the same base is not identifiable in the other. Percentage of diagnosed sites ranged from 5.1\% (between AltoPR and AltoPR-D) and 12.5\% (between Paraguay-A and Paraguay-B). Rates would probably converge close to $5 \%$ if samples were amplified. This is due to an increase in the frequency of polymorphic loci within the haplogroups, since variation in a single haplotype disqualifies the site for diagnosis.

Table 2. Number (below the diagonal) and percentage (above the diagonal) of nucleotide sites, outside the 32-bp block, which discriminate haplogroups from the hypervariable region D-loop ( $392 \mathrm{bp})$ of Astyanax from the upper Paraná and upper Paraguay River basins.

\begin{tabular}{lcccc}
\hline Haplogroup & AltoPR & AltoPR-D & Paraguay-A & Paraguay-B \\
\hline AltoPR & - & 5.1 & 8.9 & 10.2 \\
AltoPR-D & 20 & - & 9.4 & 8.9 \\
Paraguay-A & 35 & 37 & - & 12.5 \\
Paraguay-B & 42 & 35 & 49 & - \\
\hline
\end{tabular}

The genetic divergence among haplogroups may also be expressed by phylogenetic analysis of the maximum likelihood (Figure 3) constructed with model HKY85 $+\mathrm{I}+\Gamma$. Analysis confirms what may be perceived by observation of polymorphic nucleotide sites as shown in Table 1. Dendrogram shows four clearly defined haplogroups. In fact, the two haplogroups of the upper Paraná River remained distant from each other but they are intercalated by the two Astyanax haplogroups of the Paraguay River.

\section{DISCUSSION}

Many research groups from several Brazilian institutions have investigated A. altiparanae from the upper Paraná River based on traditional, cytogenetic and molecular genetic system. Cytogenetic polymorphism has been reported among samples of $A$. altiparanae popu- 
lations from several rivers of the upper Paraná River basin (Pacheco et al., 2001; Fernandes and Martins-Santos, 2004; Ferreira Neto et al., 2009; Kantek et al., 2009; Kavalco et al., 2011). Based on chromosome polymorphism studies, it has been suggested that A. altiparanae comprises a set of species as in other Astyanax groups (Fernandes and Martins-Santos, 2004). Soria et al. (2003) and Soria (2004) reported a mitochondrial molecular diversity in the group identified as A. altiparanae.

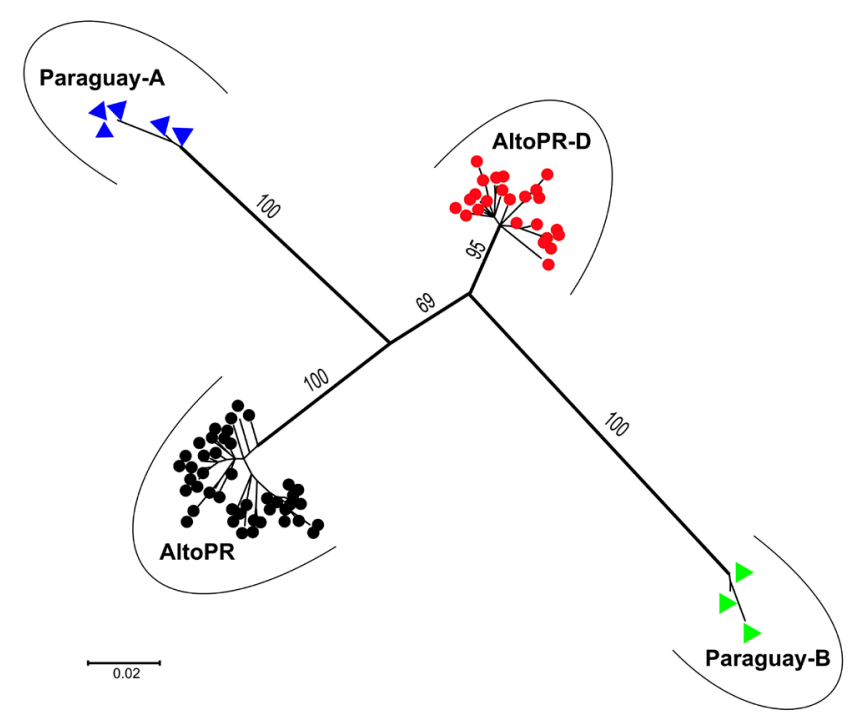

Figure 3. Dendrogram of maximum likelihood from model HKY $85+\mathrm{I}+\Gamma$ (parameters: $N_{\mathrm{ST}}=2 ; \mathrm{T}_{\text {Ratio }}=5.3719$; Rates $=$ gamma $\alpha=0.6798$; Pinvar $=0.3726)$ as from the nucleotide sequence of the control region of mitochondrial DNA (D-loop) of Astyanax from the upper Paraná and the upper Paraguay River basins. Numbers above branches are bootstrap values based on 1000 replicates.

Similarly, A. asuncionensis has also been studied in the Paraguay River basin. No reports on highly diversification within the group are extant, with exception of the research by Soria (2004). It should be emphasized that a clear discrimination between A. altiparanae and A. asuncionensis was not possible by using usual morphological characteristics. Even if they existed, it would not be surprising that the coexistence of morphotypes was not detected not only in the upper Paraná River but also in the Paraguay River basin.

The D-loop region is different from other regions of mitochondrial DNA due to its high variability. Accumulated mutations in the hypervariable extremity $5^{\prime}$ of the D-loop heavy strand provide adequate differences as molecular markers in intra- and inter-specific levels for fish studies (Sivasundar et al., 2001; Oliveira et al., 2002; Prioli et al., 2002; Ortí et al., 2008; Pie et al., 2009). Differences may be shown even though the species are highly similar. It should be observed that the analysis employed in this study discarded indels. Therefore, the difference shown at this point is not the result of a sudden loss or addition from a great block of base pairs; rather the divergence would be the result of a long accumulating process of specific differences. Nucleotide divergences of the same nature and greatness are met in many proximate fish species. 
Current differentiation level among the four haplogroups lies at the same level as that found between proximate species, albeit isolated in their natural environment with regard to reproduction. For instance, Pseudoplatystoma corruscans and P. fasciatum are two Pimelodidae species that naturally do not produce hybrids, except in forced conditions of hormonal induction undertaken in the laboratory. Natural hybrids are not found in regions in which they occur in sympatry. However, only $5.3 \%$ of nucleotide sites at the same extremity of the D-loop region may be employed to diagnose the two species (Bignotto et al., 2009). Another well-documented situation occurs with Cichla kelberi and C. piquiti, which naturally inhabit the Tocantins/Araguaia basin and were transposed to the upper Paraná River basin. Oliveira et al. (2006) showed that D-loop region's variable extremity of the two species differs approximately $10 \%$ with regard to nucleotide sites. A. altiparanae of the haplogroup AltoPR in the current study and A. bifasciatus Garavello \& Sampaio, 2010 (formerly called Astyanax sp B), endemic species to the Iguaçu River basin, are highly different, even though, at D-loop extremity, only about $20 \%$ of nucleotide sites differentiate the two species (Prioli et al., 2002).

Rates for above-mentioned species are very similar to those found among the studied haplogroups, or rather, the percentage of diagnosed sites ranged from $5.1 \%$ between AltoPR and AltoPR-D to $12.5 \%$ between Paraguay-A and Paraguay-B. D-loop divergences in all comparisons with haplogroups are incompatible with what is expected for intra-species variations. It allows concluding that haplogroups AltoPR and AltoPR-D are not variants of A. altiparanae. Moreover, sequence results showed that haplogroups AltoPR-D from the upper Paraná River, without the 32-bp block, do not coincide with the haplogroups without the 32-bp block Paraguay-A and Paraguay-B, native to the Paraguay River basin.

Therefore, the suggestion that the four haplogroups documented in the current investigation correspond to a complex group, with at least four species, is supported. Two of the species would be coexisting in the upper Paraná River, whereas the other two species would inhabit the Paraguay River basin. Owing to the great number of sequences analyzed and the wide distribution of sampling sites, it is highly unlikely that any dispersed haplogroup would have passed unnoticed in the upper Paraná River. In fact, geographically isolated haplogroups may exist. However, the situation is different in the Paraguay River basin. The genetic diversity in the region may not have been properly sampled with the analysis of merely eight specimens. More sites and a greater number of specimens should be sampled in the future.

The traditionally morphological traits used in the taxonomy of Astyanax are insufficient to consistently discriminate the morphotypes of the altiparanaelasuncionensis group. Unusual morphological characteristics in taxonomy have not yet been employed for the identification of species in this group. It may be possible that such an approach would be successful in the characterization of not yet recognized morphotypes.

The above genetic information in itself would be contrary to the suggestion by Soria (2004) that the genetic variant without 32-bp block found in the upper Paraná River (AltoPRD) would correspond to $A$. asuncionensis, which became an invader when the Itaipu was impounded. Furthermore, the haplogroup AltoPR-D was reported in the Grande River and in the Tietê River. Owing to the geographical isolation caused by the erstwhile Marimbondo Waterfall and currently by the dam of the Marimbondo reservoir, it may be suggested that AltoPR-D specimens have not colonized the upper Paraná River basin after Itaipu reservoir impoundment. Although there would still be the possibility of re-population of the reservoirs with matrixes of the AltoPR-D haplogroups, no information on this point was given. 
No indication exists that the haplogroup AltoPR-D would have originated in another place and that only recently it colonized the upper Paraná River. It seems that its distribution is wide. If it did not originate in the upper Paraná River, it would possibly have originated in the region or it has already been incorporated to the ichthyofauna of the upper Paraná River, many generations prior to the formation of the Itaipu reservoir.

The current investigation showed evidence on the high genetic variations within the altiparanaelasuncionensis group of Astyanax, which seemingly is highly homogenous in its morphology and suggests the existence of a cryptic species complex. The above information will certainly be a contribution towards describing and mapping the diversity within the genus Astyanax.

\section{ACKNOWLEDGMENTS}

The authors gratefully acknowledge A.A. Agostinho for valuable discussions and suggestions, W.J. Graça for assisting with species identification, E.K. Okada for helping with fish sampling, and Nupélia-UEM for logistic support, CNPq-PELD (site 6) and Furnas Centrais Elétricas for finantial support, and CAPES for fellowships.

\section{REFERENCES}

Agostinho AA and Júlio HF Jr (1999). Peixes da Bacia do Alto Rio Paraná. In: Ecologia de Comunidades Tropicais (Lowe-Mcconnel RH, ed.). EDUSP, São Paulo, 375-399.

Agostinho AA, Júlio HF Jr and Boeguetti JR (1992). Considerações sobre os impactos dos represamentos na ictiofauna e medidas para a sua atenuação. Um estudo de caso: reservatório de Itaipu. Rev. UNIMAR 14: 89-107.

Agostinho AA, Júlio HF Jr and Petrere M (1993). Itaipu Reservoir: Impacts of the Impoundment on Fish Fauna and Fisheries. In: Rehabilitation of Freshwater Fisheries (Cowx I, ed.). Oxford Press, Fishing News Books, New York, 171-184.

Avise JC (2004). Molecular Markers, Natural History, and Evolution. 2nd edn. Sinauer Associates, Sunderland.

Batista JS and Alves-Gomes JA (2006). Phylogeography of Brachyplatystoma rousseauxii (Siluriformes - Pimelodidae) in the Amazon Basin offers preliminary evidence for the first case of "homing" for an Amazonian migratory catfish. Genet. Mol. Res. 5: 723-740.

Bignotto TS, Prioli AJ, Prioli SMAP, Maniglia TC, et al. (2009). Genetic divergence between Pseudoplatystoma corruscans and Pseudoplatystoma reticulatum (Siluriformes: Pimelodidae) in the Paraná River Basin. Braz. J. Biol. 69: 681-689.

Britski H, Silimon KZS and Lopes BS (2007). Peixes do Pantanal. Manual de Identificação. Embrapa, Brasília.

Faber JE and Stepien CA (1977). The Utility of Mitochondrial DNA Control Region Sequences for Analyzing Phylogenetic Relationships Among Populations, Species, and Genera of the Percidae In: Mol. Syst. Fishes (Kocher TD and Stepien CA, eds.). Academic Press, New York, 129-143.

Fernandes CA and Martins-Santos IC (2004). Cytogenetic studies in two populations of Astyanax altiparanae (Pisces, Characiformes). Hereditas 141: 328-332.

Ferreira Neto M, Vicari MR, Camargo EF, Artoni RF, et al. (2009). Comparative cytogenetics among populations of Astyanax altiparanae (Characiformes, Characidae, Incertae sedis). Genet. Mol. Biol. 32: 792-796.

Garutti V (1995). Revisão Taxonômica dos Astyanax (Pisces, Characidae), com Mancha Umeral Ovalada e Mancha no Pedúnculo Caudal, Estendendo-se à Extremidade dos Raios Caudais Medianos, das Bacias do Paraná, São Francisco e Amazônica. Free-Docent thesis, Universidade Estadual Paulista Júlio de Mesquita Filho, UNESP, São José do Rio Preto.

Garutti V and Britski HA (2000). Descrição de uma espécie nova de Astyanax (Teleostei: Characidae) da bacia do alto Rio Paraná e considerações sobre as demais espécies do gênero na bacia. Comum. Mus. Ciênc. Tecnol. PUCRS Ser. Zool. 13: 65-88.

Graça WJ and Pavanelli CS (2002). Astyanax altiparanae Garutti \& Britski, 2000 (Osteichthyes, Characidae) in the Iguaçu River basin. Acta Sci. 24: 451-453.

Guindon S and Gascuel O (2003). PhyML - A simple, fast, and accurate algorithm to estimate large phylogenies by maximum likelihood. Syst. Biol. 52: 696-704.

Hall TA (1999). BioEdit: a user-friendly biological sequence alignment editor and analysis program for Windows 95/98/ NT. Nucleic Acids Symp. Ser. 41: 95-98. 
Júlio HF Jr, Tós CD, Agostinho AA and Pavanelli CS (2009). A massive invasion of fish species after eliminating a natural barrier in the upper rio Paraná basin. Neotrop. Ichthyol. 7: 709-718.

Kantek DL, Vicari MR, Peres WA, Cestari MM, et al. (2009). Chromosomal location and distribution of As51 satellite DNA in five species of the genus Astyanax (Teleostei, Characidae, Incertae sedis). J. Fish Biol. 75: 408-421.

Kavalco KF, Pazza R, Brandao KD, Garcia C, et al. (2011). Comparative cytogenetics and molecular phylogeography in the group Astyanax altiparanae - Astyanax aff. bimaculatus (Teleostei, Characidae). Cytogenet. Genome Res. 134: 108-119.

Lima FCT, Malabarba LR, Buckup PA, Silva JFP, et al (2003). Genera Incertae sedis in Characidae. In: Checklist of the Freshwater Fishes of South and Central America (Reis RE, Kullander SO and Ferraris CJ Jr, eds.). EDIPUCRS, Porto Alegre, 106-168.

Meyer A (1994). DNA Technology and Phylogeny of Fish. In: Genetics and Evolution of Aquatic Organisms (Beaumont AR, ed.). Chapman and Hall, London, 219-249.

Meyer A, Kocher TD, Basasibwaki P and Wilson AC (1990). Monophyletic origin of Lake Victoria cichlid fishes suggested by mitochondrial DNA sequences. Nature 347: 550-553.

Monesi N, Jacobs-Lorena M and Paçó-Larson ML (1998). The DNA puff gene BhC4-1 of Bradysia higida is specifically transcribed in early prepupal salivary glands of Drosophila melanogaster. Chromosoma 10: 559-569.

Nei M and Kumar S (2000). Molecular Evolution and Phylogenetics. Oxford University Press Inc., New York.

Oliveira AV, Prioli AJ, Prioli SM, Pavanelli CS, et al. (2002). Diversity and genetic distance in populations of Steindachnerina in the upper Parana river floodplain of Brazil. Genetica 115: 259-267.

Oliveira AV, Prioli AJ, Prioli SMAP, Bignotto TS, et al. (2006). Genetic diversity of invasive and native Cichla (Pisces: Perciformes) populations in Brazil with evidence of interspecific hybridization. J. Fish Biol. 69: 260-277.

Ortí G, Sivasundar A, Dietz K and Jégu M (2008). Phylogeny of the Serrasalmidae (Characiformes) based on mitochondrial DNA sequences. Genet. Mol. Biol. 31: 343-351.

Pacheco RB, Giuliano-Caetano L and Dias AL (2001). Occurrence of cytotypes and multiple NORs in an Astyanax altiparanae population (Pisces, Tetragonopterinae). Chromos. Sci. 5: 109-114.

Panarari-Antunes RS, Prioli AJ, Prioli SM, Julio HF Jr, et al. (2008). Molecular variability in Brycon cf. pesu Muller and Troschel, 1845 (Characiformes: Characidae) from the Araguaia-Tocantins Basin. Genet. Mol. Res. 7: 95-106.

Pie MR, Baggio RA, Boeger WA, Patella LA, et al. (2009). Molecular data reveal a diverse Astyanax species complex in the upper Iguacu River. J. Fish Biol. 75: 2357-2362.

Posada D and Crandall KA (1998). MODELTEST: testing the model of DNA substitution. Bioinformatics 14: 817-818.

Prioli SMAP, Prioli AJ, Júlio HF Jr, Pavanelli CS, et al. (2002). Identification of Astyanax altiparanae (Teleostei, Characidae) in the Iguaçu River, Brazil, based on mitochondrial DNA and RAPD markers. Genet. Mol. Biol. 25: 421-430.

Rokas A, Ladoukakis E and Zouros E (2003). Animal mitochondrial DNA recombination revisited. Trends Ecol. Evol. 18: 411-417.

Sivasundar A, Bermingham E and Orti G (2001). Population structure and biogeography of migratory freshwater fishes (Prochilodus: Characiformes) in major South American rivers. Mol. Ecol. 10: 407-417.

Soria TV (2004). Diversidade em Seqüências da Região Controle do DNA Mitocondrial de Populações de Astyanax da Bacia do Alto Rio Paraná. Master's thesis, Universidade Estadual de Maringá, Maringá.

Soria TV, Prioli AJ, Prioli SMAP, Prioli LM, et al (2003). Diversidade na Região D-loop do DNA Mitocondrial de Astyanax altiparanae (Pisces, Characiformes) da Planície de Inundação do Alto Rio Paraná. Anais do $49^{\circ}$ Congresso Nacional de Genética, Águas de Lindóia. 